\title{
Paul-André Claudel, Le Poète sans visage. Sur les traces du symboliste A.J. Sinadino (1876-1956)
}

\section{Maria Emanuela Raffi}

\section{(2) OpenEdition}

1 Journals

\section{Edizione digitale}

URL: http://journals.openedition.org/studifrancesi/7681

DOI: 10.4000/studifrancesi.7681

ISSN: 2421-5856

\section{Editore}

Rosenberg \& Sellier

\section{Edizione cartacea}

Data di pubblicazione: 1 décembre 2009

Paginazione: 659-660

ISSN: 0039-2944

\section{Notizia bibliografica digitale}

Maria Emanuela Raffi, «Paul-André Claudel, Le Poète sans visage. Sur les traces du symboliste A.J.

Sinadino (1876-1956)», Studi Francesi [Online], 159 (LIII | III) | 2009, online dal 30 novembre 2015, consultato il 09 janvier 2021. URL: http://journals.openedition.org/studifrancesi/7681 ; DOI: https:// doi.org/10.4000/studifrancesi.7681

Questo documento è stato generato automaticamente il 9 janvier 2021.

\section{(c) $(1) \ominus$}

Studi Francesi è distribuita con Licenza Creative Commons Attribuzione - Non commerciale - Non opere derivate 4.0 Internazionale. 


\title{
Paul-André Claudel, Le Poète sans visage. Sur les traces du symboliste A.J. Sinadino (1876-1956)
}

\author{
Maria Emanuela Raffi
}

\section{NOTIZIA}

PAUL-ANDRÉ CLAUDEL, Le Poète sans visage. Sur les traces du symboliste A.J. Sinadino (1876-1956), Paris, PUPS, 2008, pp. 409.

1 Benché cronologicamente al limite di questa zona della Rassegna, la formazione simbolista di Agostino John Sinadino e il suo carattere determinante nell'opera poetica, che sconfina largamente nel secolo successivo, consentono di presentarlo nella seconda metà del XIX secolo, dove trova radici profonde e strutturanti. Poco conosciuto e forse volutamente poco conoscibile, questo autore, che ha pubblicato un'opera poetica non molto estesa, redatta in buona parte in lingua italiana (Le presenze invisibili 1898, La donna degli specchi 1899, Melodie 1900, Poésies 1902-1925, 1929 e alcune altre raccolte), sembra aver fatto proprio il principio mallarmeano di «être le dernier et le suprême écrivain, donnant tout au livre et rien à la vie».

2 Merito di Paul-André Claudel è dunque anzitutto quello di aver proposto, anche con la riproduzione di copertine originali delle opere e con un'ampia indagine critica, accompagnata da una ricca bibliografia, la conoscenza di questo poeta viaggiatore e sperimentatore e del suo composito itinerario di vita (da Alessandria d'Egitto a Milano, Parigi, New York) e soprattutto di scrittura, dato che a quest'ultima Sinadino riconosce la non banale capacità di ricomporre il mondo: «Sinadino finit par suggérer que cette parole écrite est la seule vérité qui soit à la fois accessible et certaine: la page est le lieu où fixer le monde». 